\title{
Lusioersily
}

\section{Portugal: the Spatial Impact of the EFTA Industrial Development Fund}

Eaton, M. (1993). Portugal: the Spatial Impact of the EFTA Industrial Development Fund. Geoforum, 24(4), 423433.

Link to publication record in Ulster University Research Portal

Published in:

Geoforum

Publication Status:

Published (in print/issue): 01/01/1993

\section{Document Version}

Publisher's PDF, also known as Version of record

\section{General rights}

Copyright for the publications made accessible via Ulster University's Research Portal is retained by the author(s) and / or other copyright owners and it is a condition of accessing these publications that users recognise and abide by the legal requirements associated with these rights.

\section{Take down policy}

The Research Portal is Ulster University's institutional repository that provides access to Ulster's research outputs. Every effort has been made to ensure that content in the Research Portal does not infringe any person's rights, or applicable UK laws. If you discover content in the Research Portal that you believe breaches copyright or violates any law, please contact pure-support@ulster.ac.uk. 


\title{
Portugal: the Spatial Impact of the EFTA Industrial Development Fund
}

\author{
MARTIN EATON,${ }^{*}$ Coleraine, Northern Ireland
}

\begin{abstract}
More than half of the projected lifespan of the EFTA Industrial Development Fund (IDF) for Portugal has now been completed, although the spatial efficacy of help available to Portuguese industry through this medium has met with a variable level of success. The main argument shows that, whilst overall management of the fund continues to be spatially and sectorally biased in favour of those companies in regions least in need, there does appear to be a fresh potential for industrial development in some of the more disadvantaged areas of Portugal. A series of recommendations points to improved advertising for the IDF so as to ensure that recent improvements continue and to allow for the Fund's regional development potential to be realised.
\end{abstract}

\section{Introduction}

Portugal's entry into the European Free Trade Association (EFTA) in the late 1950s is now seen as a major turning point, both in the policies pursued by the dictator Salazar and as the beginning of a move towards the Europeanisation of the Lusoeconomy (KOHLER, 1982, p. 174; MACHADO, 1987, p. 126).

The relationship between EFTA and Portugal has developed slowly since its inception in 1960 and, although Portugal's current destiny lies within the European Community (EC), both the trade links and systems for helping each other remain strong (EFTA, 1987, pp. 29-30). The Industrial Development Fund (IDF) is one such scheme of assistance and represents an attempt by the wealthier members of EFTA to bring Portugal's industrial structures and, in turn, that of its economy much more in line with the rest of the free trading area. The history and politics of the Fund are dealt with elsewhere [see EATON (1991)], although we should recognise, at the outset, that as a

*Department of Environmental Studies, University of Ulster, Coleraine, BT52 1SA, Northern Ireland. tool for economic development $O$ Fundo EFTA is in need of re-evaluation and this work represents the first discussion of such change.

Because there is only limited literature on this topic (in both Portuguese and English) this paper makes a contribution to the theory of Portuguese industrial policy and its subsequent impact in a peripheral member-state of the EC. The author attempts to show whether or not the IDF has the power to produce the desired effect, namely, the reduction of disparities between industrial structures throughout all of Portugal and not just in the more overdeveloped coastal margin [see SILVA (1992) and GASPAR and JENSEN-BUTLER (1992) for useful accounts of this spatial phenomenon]. A secondary analysis is made of some of the more recent (1989-1991) activities carried out by the Fund, with a focus on the sectoral and spatial application of finance. This paper also emphasises the rôle played in both job creation and training support with a view to assessing the relative improvement of the Portuguese human resource base in recent years. This work concludes by criticising one particular aspect of the IDF's operations-its regional maldistribution of aid-and offers some comment on how the spatial dimension is being gradually 
424

altered through an assessment of IDF funding per Portuguese economically active person (EAP). This latter finding is one which up until now has been subsumed in writings on the Fund and is perhaps a policy direction which EFTA should be pursuing more vigorously.

\section{IDF Activities}

By the end of January 1991 the EFTA IDF for Portugal had completed well over half of its projected 25-year lifespan. Thus far, the Fund's story has been one of struggle for recognition and one of perseverance to improve from a sluggish start. During the early years, the Fund's lending activity was "relatively modest" (EFTA, 1990, p. 1). In the first 4 years of operation less than 40 loans were granted for an amount equivalent to just over 1 billion escudos. The tight monetary policy adopted by the Portuguese government in 1993 (BOGDANOWICZBINDERT, 1983) actually led to an overall fall in the Fund's lending activity. In fact it was only after a major publicity campaign in 1985 that the IDF was able to double the amount lent, although significantly it had taken until its ninth year of operations to reach 'lift-off'. In its tenth year, coupled with surging capital investments from foreign sources (HUDSON, 1989; WISE, 1990), the amount lent doubled again and the Fund attained its "cruising speed" (EFTA, 1990, p. 1).

One of the most recent IDF reports for the thirteenth year of operations shows a new impetus for lending activity; in 1989-1990 a total of 95 loans were granted for an overall and direct input of almost 9 billion escudos or a sum equivalent to $£ 3.6$ million. That fresh impetus was curtailed in 1990-1991 with just 60 (admittedly larger-scale) projects being part-financed and disbursements amounting to just 8.2 billion escudos. Over the whole of the Fund's life a grand total of 732 loans have been approved, amounting to around 50 billion escudos worth of direct loan finance [see EFTA (1990, pp. 2-5; 1991, p. 14)]. Clearly, in a difficult national business environment a loan can be a lifeline to future expansion and success, particularly, as will be seen, when it is delivered on preferential terms. Such arrangements have a clear potential therefore to help both industrial and regional development in Portugal.
However, and in the context of this discussion, it should be acknowledged that, in relation to other external funding (from the EC for instance), the amounts provided by EFTA are small (ARANTES, 1991). To take one example, the European Investment Bank in just 1 year (1989) provided Portugal's industry and infrastructure with loans to the tune of 130 billion escudos, a figure more than 14 times that for IDF in the same year (EIB, 1990). However, it would be wrong to dismiss $O$ Fundo EFTA as insignificant. Its contribution to Portuguese spatial development is measurable and this factor will be demonstrated later in this paper. Indeed, the IDF now serves as an important addition to the credits provided by the structural funds of the EC in association with the central government, and to a lesser degree with those of the World Bank [see Wall Street Journal (1984) and MNE (1987, 1988)].

As a condition of its activities the Fund does not normally provide all of the finance necessary for a project-it will lend around a third of the total investment with companies being expected to provide the rest, either from their own resources or by borrowing from local banks. As a result overall investment inclusive of EFTA support amounted to about 167 billion escudos over the 14-year reference period with a large proportion (73 billion, or $44 \%$ ) being created between 1989 and 1991. Furthermore, there is provisiorl in the Fund's legislation for granting loans to businesses on terms which are more favourable than those normally prevailing in the Portuguese marketplace. Since 1980, the Fund has used a flexible interest rate which is connected to national interest rate rebates. The levy is revised periodically and in line with overall conditions in the Portuguese economy (OECD, 1991) such that its competitiveness as a source of support is maintained. This is a vital factor in an economy where the vagaries of the European financial markets can often be grave, and where local, commercial banks are often unwilling to provide preferential treatment because of the risks involved.

It is interesting to note that IDF loans made available in 1990-1991 were used mainly for the purchase and assembly of new equipment ( $61 \%)$, and for building and construction work $(34 \%)$, the latter being used either to establish new companies or to expand/ modernise existing plants. Virtually all of the loans 
Table 1. Allocation of IDF loans by 10 most important sectors of activity, 1977-1991*

\begin{tabular}{lcccc}
\hline & $\begin{array}{c}\text { Loans } \\
\text { granted } \\
\text { Sumber of } \\
\text { operations }\end{array}$ & $\begin{array}{c}\text { Total } \\
\text { contos) }\end{array}$ & $\begin{array}{c}\text { project } \\
\text { investment } \\
\text { (million contos) }\end{array}$ & $\begin{array}{c}\text { Number of } \\
\text { jobs } \\
\text { created }\end{array}$ \\
\hline Foodstuffs/beverages & 161 & 10.5 & 26.9 & 1205 \\
Textiles/clothes & 63 & 5.0 & 17.9 & 988 \\
Agriculture/livestock/fisheries & 93 & 4.4 & 10.4 & 998 \\
Paper/printing & 30 & 4.8 & 30.0 & 127 \\
Electrical equipment & 44 & 3.3 & 6.5 & 702 \\
Hotels & 32 & 4.6 & 17.8 & 820 \\
Fabricated metal products & 45 & 2.3 & 6.2 & 725 \\
Wood/furniture & 37 & 1.5 & 6.0 & 605 \\
Non-metallic products & 34 & 1.9 & 5.1 & 510 \\
Mining/quarrying & 33 & 1.4 & 3.2 & 408 \\
Others & 160 & 10.0 & 36.7 & 1992 \\
Total & 732 & 49.7 & 166.7 & 9080 \\
\hline
\end{tabular}

*Source; EFTA (1991, p. 14).

made over the period (1977-1991) were approved for private firms as against publicly-owned enterprises. A ratio of $92 \%: 8 \%$ reflects the ruling Social Democratic policy of supporting privatisation in Portuguese industry and giving less public funding to state-owned companies (CORKHILL, 1991; WILLIAMS, 1992). These changes are enshrined in the new Portuguese constitution [see EIRR (1989)] and demonstrate a major policy shift towards a mixed economic democracy [as described by OECD (1989)]. It will be seen shortly how this orientation towards the private sector is reflected in the areal performance of the Fund since it is the expansion of the free market and (often) the small business which is seen as essential to Portugal's industrial prosperity.

\section{Application of Funds by Branch of Activity}

To its credit the IDF distributes loans to a wide range of economic activities (see Table 1). By far the most important sector in terms of loans granted has been that of foodstuffs and beverages, accounting for over one-fifth of the total loans allocated over the 14 years of operation. Traditional sectors such as viniculture and fish processing have all been supported through the IDF, coupled (over the last 3 years) with more modern activities such as aquaculture, milk processing, soya bean conversion and environmental science research. This shift towards modern food-processing techniques, information research and technology is part of a conscious effort to kick-start the Portuguese economy into the twenty-first century and to allow it to function on a more even footing with the rest of western Europe.

This Europeanisation of production is particularly important for secondary activities since it is this sector which benefits the most from higher values-added to production through exports. Consequently, $79 \%$ of loans (in 1990-1991) were granted to manufacturing companies, although increasingly allocations have been made to the service sector $(9 \%)$ and most of the remaining $12 \%$ was directed towards the primary agricultural, livestock, fisheries, mining and quarrying sectors. For the very first time modern sectors such as agro-tourism and professional training in new technologies received attention. This trend again reflected heightened awareness of the need to both diversify and improve the quality, and, thereby again, the competitive position of Portuguese industry (RODRIGUES, 1991). In turn, the spin-off effects which benefit the national economy are crucial and it is this national-scale response or contribution to the image building of Portuguese economic dynamism which is behind much of the application of IDF loans.

This point is reiterated by the fact that several sectors of manufacturing have now benefited from spiralling loan applications. Amongst them, the paper and printing industries, foodstuffs and beverages, wood and furniture sectors stand out. The amount of credit given to the hotel sector also expanded (some $3 \frac{1}{2}$ times the previous year) and interestingly it is those sectors 


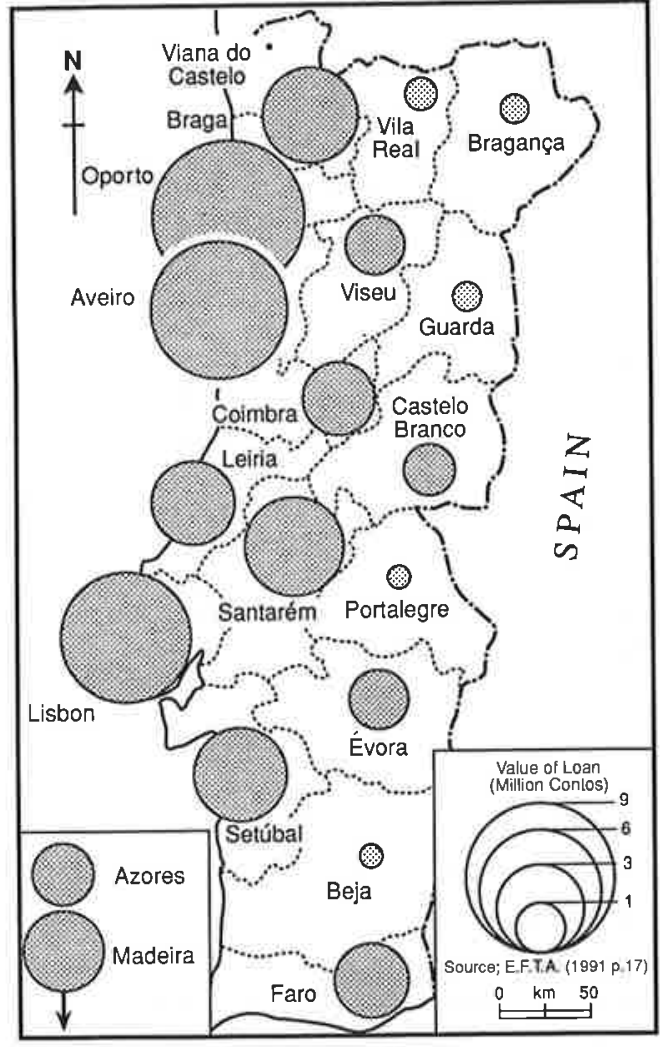

Figure 1. Distribution of IDF loans, 1977-1991.

which are often leaders within Portuguese export trade and/or more modern service providers which were being helped considerably by the Fund at this time (Expresso, 1991). Again, it is the supranational image which is being consolidated, the performance of Portugal in the international marketplace is being boosted and yet at the same time (and as will be seen below) it is the spatial performance of the Fund which is being both enhanced and restricted (in almost equal measure).

\section{Spatial Distribution of Operations Approved}

EFTA's (recent) annual reports reflect this erratic performance by claiming that the Fund has maintained its policy of fostering investment in lessdeveloped areas of the country. Whilst counties such as Vila Real, Bragança, Castelo Branco and Viseu had been targeted in the years under review, the reports fail to mention that Lisbon and Oporto distritos (counties) remain top of a list of spatiallyapproved loans.

Figures 1 and 2 show that, rather than diminishing regional inequalities, the IDF appears to be exacerbating the problems of under- and overdevelopment in different parts of Portugal. The dominant spatial dichotomy in Portugal (that of the coastal-interior division) is being reinforced by the patterns of funding shown in Figures 1 and 2. This finding holds despite EFTA rhetoric to the contrary and despite its own statutes requiring the IDF to pay particular attention to regional issues. In fairness, and in its very first annual report (EFTA, 1978, p. 8) the Association acknowledged that "the centre of gravity for loans (was) the most industrialised parts of Portugal". To date, the evidence suggests that the IDF has been unable to break away from a spatial polarisation of help aimed at the Portuguese coastal margin (an area which Figure 3 confirms is the economically active core for Portugal). EFTA $(1978$, p. 8) quickly recognised problems with this orientation and reacted by saying that "the Fund will try in future to meet the needs of the less-developed regions in Portugal". By 1990, the Fund was still "maintaining its policy of trying to foster investment in less-developed areas of the country" (EFTA, 1990, p. 6). Yet, clearly, the weight of spatial evidence given in Figures 1 and 2 hangs as a cloud over the workings of the IDF and there is still a good deal to be done if a more equitable application of loans is to be achieved and its own policy directives are to be accomplished.

IDF spatial evidence at face value is disappointing since the coastal axis from Braga in the north through Oporto, Aveiro, Coimbra, Leiria, Santarém, Lisbon, Setúbal and Faro in the far south dominates the national picture (Figure 1). The more isolated interior regions to the north and east, close to the Spanish border, have been allocated limited amounts of finance (note the derisory allocation for Viana do Castelo distrito and the negligible applications in Vila Real, Bragança, Guarda, Portalegre and Beja counties). In part, this dearth of funding explains the continued neglect of such cross-border regions (JOLIFFE, 1992) but the biggest problem is with the lack of cooperative measures between Portuguese and Spanish partners in these areas. That physical isolation is then re-emphasised when Portugal's own development agencies (of which IDF is a part) fail to rejuvenate such marginal space. The harshness of life in these areas is a sad reflection of their status as one of the EC's most impoverished regions and as the Single European Market comes into affect even the 
.

ant spaterior

of fund-

ding holds

despite its

particular

and in its very

the Associ-

of gravity for

of Portugal"

IDF has been

plarisation of

gin (an area

cally active

jickly recog

d reacted by

to meet the

portugal". By

its policy of

ped areas of

clearly, the

ures 1 and 2

IDF and

and its own

disappointing lisappointing arém, Lisbon,

dominates the

ore isolated

close to the

ted amounts

for Viana do

cations in Vila

d Beja coun-

3 explains the

rder region

$\mathrm{m}$ is with the

Portuguese

That physical

That physical

ortugal's own

a part) fail to

shness of life

status as one

and as the

fect even the

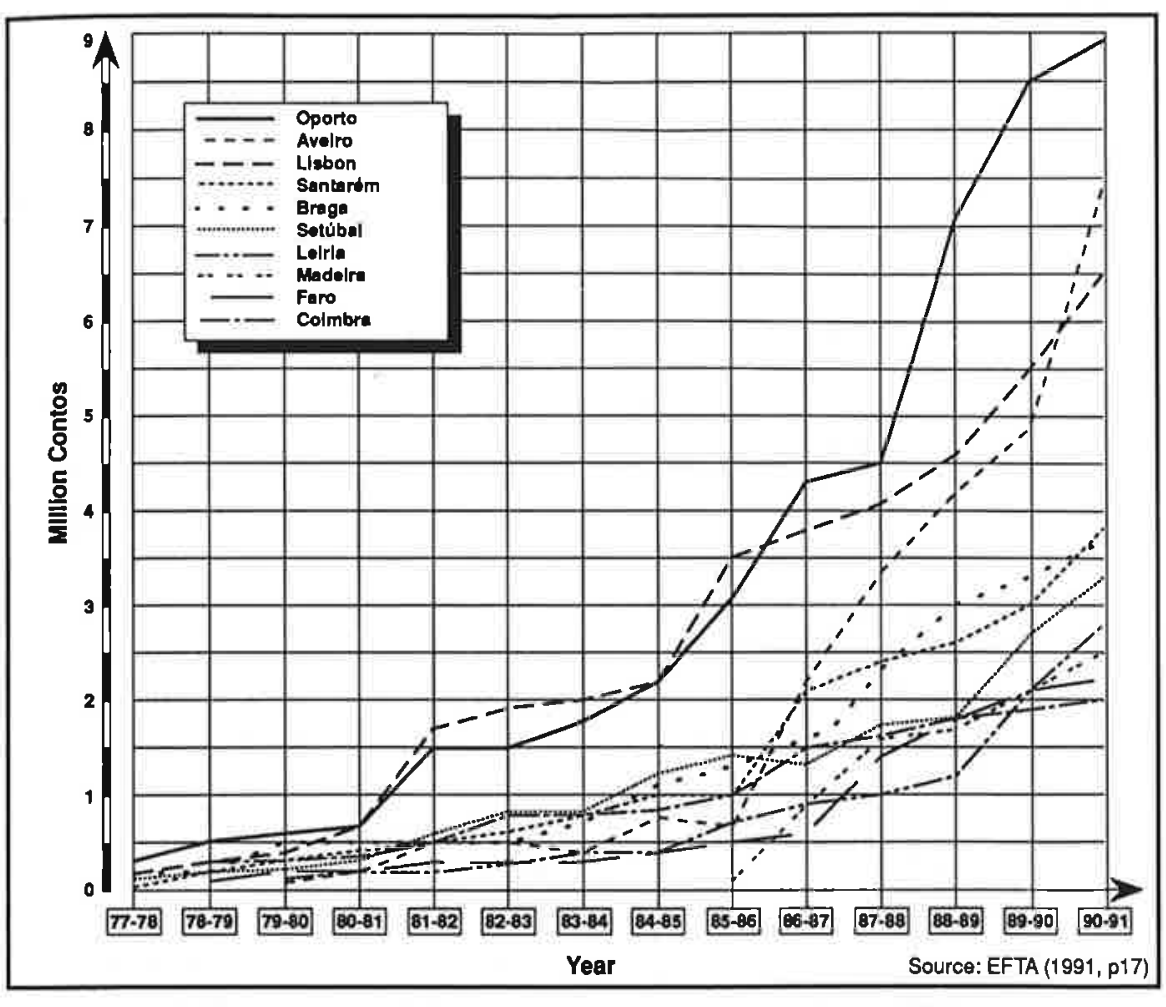

Figure 2. Evolution of IDF loans by county, 1977-1991.

traditional means of economic survival heresmuggling-will probably fall into decline and so the difficulties with the development process will become even greater.

Figure 2 shows that investment in the counties of Oporto and Lisbon is rapidly outstripping the credits being applied to countes locted between the 'big two'. They, in turn, are outstripping the amount of money being applied to the spatial peripheries of Portugal. The fundamental question to be answered, Portugal. The fundamental question to be answered, therefore, is do you attempt to reduce regional disparity by channelling funds to the coast or do you change direction and concentrate efforts in the interior? In simple theoretical terms the solution is easy-you endeavour to improve allocations to counthes in the far north and east of Portugal by disseminating information on the IDF to a much wider (and arguably just as deserving) audience. Because a actory owner chooses to locate (LEWIS and WILLIAMS, 1988) in the interior regions does not mean that he or she should be denied acsess to funds simply because the majority of businesses are found in the western coastal margin (FERRĀO, 1988). Such a

process is neither margin (FERRAO, 1988). Such a ironing out of Portugal's 'regional problem'-its spatial dichotomy. A number of authors (FERRAO, 1986; CAETANO, 1986; LEWIS et al., 1986; EATON, 1988; SYRETT, 1991) have identified the mechanics behind industrialised, industrialising and dynamic rural concelhos (parishes) in Portugal, and it fair to say that the labour market in many of these peripheral areas is based on independent entrepersh pros -

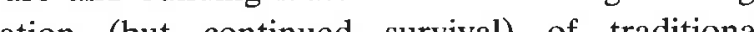

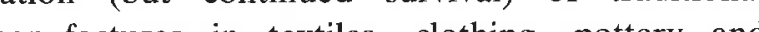
mences ger for (a) opportunities (and fairer access to

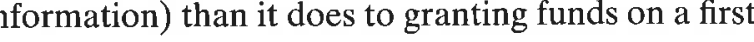
che frst-served basis. The author feels that EFTA hould be more aware of this factor when assessing company loan applications in the future and should be more selective in its allocation of assistance-most obviously with a preference for those viable project proposals being generated in the interior.

This feature is very significant because if greater 


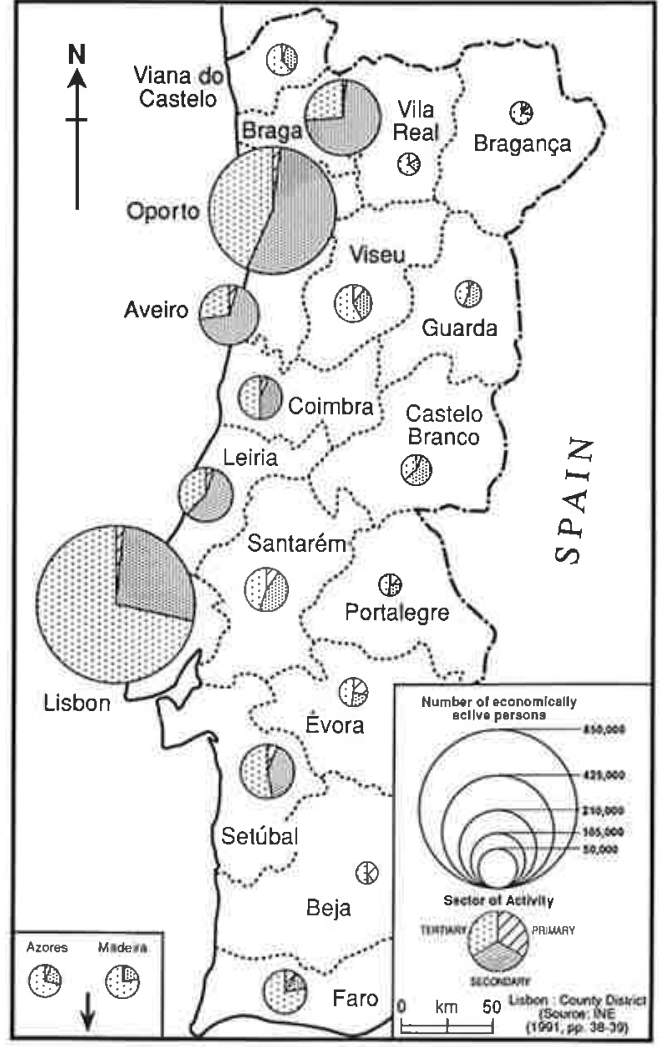

Figure 3. Distribution of Portuguese working population, 1988.

support is given to factories in the Portuguese interior this will be a vital step towards stopping internal migration to the coastal margin. Interregional population shift is a bane in Portugal which is motivated in the first instance by lack of job opportunities. If firms that are newly setting up in the interior are encouraged to expand (not just with the help of IDF but also through government IAPMEI ${ }^{1}$ and PEDIP $^{2}$ schemes) then there should be significant slowdown in patterns of depopulation [see GASPAR and JENSEN-BUTLER (1992)]. The benefits to local-, regional- and indeed national-scale development of such a process would be enormous because the Portuguese interior could then be orientated to face Spain and, in turn, the rest of the western European market, rather than as in the past allowing itself to look only towards Lisbon, Oporto, the Atlantic Ocean and beyond.

At present, it is individual firms which benefit the most from IDF allocation rather than large numbers of enterprises engaged in similar activities and located in a specific part of the country. As a result few local or regional areas are given sufficient impetus or financial clout to foster major economic development on wider scales of analysis and impact. This too is a problem which needs to be addressed and then rectified by EFTA since all of the loan arrangements have the inherent potential to exact regional change, but few have had the practical impact of narrowing regional disparity in Portugal. As ever, it is the cosmetic effect of funnelling aid to individual companies which allows them to prosper and others to decline, and when this is superimposed on the dominant regional dichotomy in Portugal the problems inevitably get much worse.

There are exceptions to this general rule and (in metaphorical terms) one of the bright spots on the horizon is the figurative improvement shown for the autonomous and peripheral island space of Madeira. From a cumulative total in 1985-1986 of 127,000 escudos worth of loans allocations, credits have increased almost 20 times to 2.5 million escudos in 1990-1991 (see Figure 2). This is a figure less than a third of the total of Oporto (8.9 million escudos) but a very significant amount nevertheless in Madeira's polarised island economy (EIU, 1989; BLUM, 1992). The majority of this input has gone to businesses engaged in tourism and so it could be argued that the funds have served to exacerbate the island's economic specialisation and, in turn, have increased the spatial dominance of the (tourist) capital-Funchal. It is a danger which needs to be recognised and then countered by the Fund's administrative bodyperhaps by encouraging smaller and more isolated (hotel) businesses to apply for credit and then treating their demands with greater alacrity than those requests emanating from the capital core. This comment does of course apply as much to continental Portugal as it does to this dislocated Madeiran situation.

If we look at the Madeiran example carefully then there are a number of reasons for the relatively large number of loans having been allocated by IDF. Firstly, the question of regionalism is high on the Madeiran political agenda and lobbying power or political awareness is much greater here; hence the authorities are more likely to have gained access to all available forms of funding. Secondly, EFTA appears to have deliberately targeted a 'peripheral' area (and an autonomous island community to boot) for loan 
application. By doing this the IDF can actually counter the claims of those reporters arguing for greater decentralisation of funding. 'Look at Madeira, look at Faro, look at Évora distritos for evidence of increases in regional aid' would be the cry. Such a statement is likely to satisfy most European and indeed Portuguese commentators, but whilst it is a step in the right direction (literally) there is still more to be done and again the author feels that IDF needs to continue to look much further afield. 'What about Viana do Castelo and Bragança?' is perhaps a more pertinent question.

\section{Job Creation}

If we now shift the focus of analysis to the labour market then on a positive note and as a direct result of projects helped by the Fund, a total of 9080 new jobs were created between 1977 and 1991. In the first year under review (1989-1990) 1429 new workposts were formed, reflecting $19 \%$ of the total number and again showing a fresh impetus for employment creation as Portugal moved into the 1990s. In 1990-1991, that impetus had slipped slightly (1213 jobs were created, which is only $15 \%$ of new work posts for the whole study period). However, and through increases in productivity and improvements in product quality and working conditions, greater security of employment has been secured for several thousand additional workers in the factories helped directly by IDF. In fact, the 1991 additions brought overall safeguarding to some 96,100 existing jobs within each of the 732 businesses helped by EFTA over the whole of the study period (from inception to 1991).

In a country plagued by high and hidden unemployment rates (KENT, 1989) this is a particularly important feature. These audited figures are an accurate indication of how IDF intervention has directly helped the volatile labour market in Portugal, although unfortunately there are no data available to demonstrate the spatial pattern of job generation by factory. Similarly, there are no figures on job creation and subsequent loss; the 'death' rate of employees are not available since the figures quoted above are merely cumulative assessments-just how permanent, whether full- or part-time, or at what level of professionalism these new employees are entering the firms is subject to wide debate. The release of such detailed statistics would clearly enhance a study of this kind although the failure to disseminate this type of information is symptomatic of a general lack of publicity for the Fund itself. The feeling remains that EFTA's steering committee is content to accept a position as an aid supplementer to Portuguese industry (playing a minor rôle behind EC funding for instance) rather than as an originator or manipulator of major change, particularly in the industrial field.

\section{Training Support}

This feeling of supplementary influence is also reflected in the fact that IDF has shown only a measure of support for training courses aimed specifically at Portuguese managers. In co-operation with the Portuguese Banco de Fomento e Exterior [National Bank for Overseas Development (BFE, 1990)] and various organisations experienced in this field, the Executive Commission of the IDF has financed most of the cost of the 1989-1991 programme. Twenty-five sessions were held and a total of 610 persons took part-most were managers and senior officers from companies benefiting, again in the first place, from the Fund's loans and credits. This is one of the minor successes of the IDF since the performance of the human resource base in Portugal continues to be a vexed issue. Complaints on the poor quality of school leavers, employees and professionals have been repeatedly voiced (CANHA, 1991) and these seminars appear to be a step in the right direction. It could be argued that it is a top-down process (from manager to employee, and a notoriously strained relationship at that) and that the IDF is only skimming the surface. In conversation with administrators it often appears that Portuguese middle and top management is aware of what a Euro-society (for example) demands and what standards it expects and requires. The breakdown comes in deciding how the existing industrial structures achieve that new point for development. Training the trainers to train the managers to train the workers in a Portuguese situation is one fraught with inconsistencies and peculiarities which only the Portuguese themselves can understand and change. On reflection, this attempt by the IDF is clearly a breakthrough and one which (however small) needs to be fostered and indeed extended, to take in more key personnel from each of the factories concerned. 
Since 1979 , the year in which these schemes were launched the number of training participants has topped 1550 . Courses are usually arranged as seminars and between 1989-1991 talks were aimed specifically at small and medium-sized companies (SMCs). Subjects covered feasibility studies, strategic planning, management control and support to decisionmaking systems, as well as production planning and control. New initiatives on the impact of 1993 on the SMCs and the importance of the Spanish market were also launched, and such dynamism is to be encouraged in the future. The two 'As'-'awareness and action'-may seem old hat to core-commentators but in a still-fledgling Eurocracy like Portugal's it is essential that they both work. There is a lingering suspicion of much of the self-congratulatory rhetoric emanating from the IDF that something which is seen to be working at the national scale conveniently neglects the maldistributions that are still occurring at the regional scale.

Therefore, a surprising but most welcome feature was that several of these seminars were organised at the regional and subregional levels. Aveiro, Agueda, Curia, Espinho, Leiria and Vila Nova de Famalição as well as the more familiar cities of Lisbon and Oporto all played host to seminars during the reference period. This followed on from seminars in 1988, held in Guimarães and Évora, and does at least suggest that information on the IDF is now starting to be disseminated to other, more peripheral parts of Portugal.

\section{IDF Funding per EAP}

Thus far, this paper has argued that IDF's fundamental problem is with its regional misallocation of aid; its defence of that application has not been as convincing as it perhaps should have been and the next section presents evidence on how the regional maldistribution of funds is slowly, if erratically, starting to change.

Figure 4 moves away from the absolute and generalised pattern of the national scale shown in Figures 1 and 2 , to the relative position of average IDF allocation per Portuguese EAP. Through each of the three reference years under consideration (from 1988 to 1991) in Figure 4, it is possible to trace the develop- ment of EFTA funding to the finest of scales-that of the micro- or individual level. These figures are a good deal more revealing because they show features related to both the spatial and temporal application of aid. One can see the tremendous upsurge associated with the record increases in funding after 1989, for example, and one can also observe the relatively small amount of funds being applied to each individual in the so-called 'core areas' of Lisbon and Oporto. ${ }^{3}$

At the state level, the figures re-emphasise the fact that IDF funding is small. On average, between 2600 (in 1988) and 3700 escudos (in 1989) was applied to each Portuguese EAP and this was equivalent to between just $£ 12.50$ and $£ 17.50$ for each EAP; both of which figures are exceptionally low inputs.

However, if one looks more carefully at the regional breakdown then there is some evidence to suggest that EFTA is starting to move away from a regional concentration of funding. On the basis of funding per individual a movement towards Portugal's mainland interior is discernible, and that funding has taken place in two phases. Figure 4 shows, firstly, that in 1989-1990 both Vila Real and Guarda (in the far north and east of Portugal) reaped in excess of 9600 escudos per $\mathrm{EAP}^{4}$ whilst Castelo Branco (in the central eastern interior) received 21,600 escudos per EAP. Secondly, in 1990-1991 Castelo Branco (again) and Évora were able to garner similarly large amounts of funding (5700 and 17,800 escudos per EAP, respectively). However, and despite these figures, the application of funding is not consistent and it appears that on a yearly basis some counties will be favoured to the relative neglect of others. Even in the periphery some distritos can be construed as being more 'peripheral' than others, hence the concentration of funding in 1989-1990 in the central interior (in Viseu, Guarda and Castelo Branco), to the continued neglect of both the far north (Bragança and Viana do Castelo) and mid-south of Portugal (i.e. Portalegre). By 1990-1991 that inconsistency was showing itself again because by now it was the distritos of Leiria, Santarém and Setúbal (the crescentshaped outskirts around the capital, Lisbon) which were receiving proportionally larger amounts of funding. There does not, therefore, appear to be a coherent spatial strategy to EFTA's operations in Portugal and the steering committee appears to be 


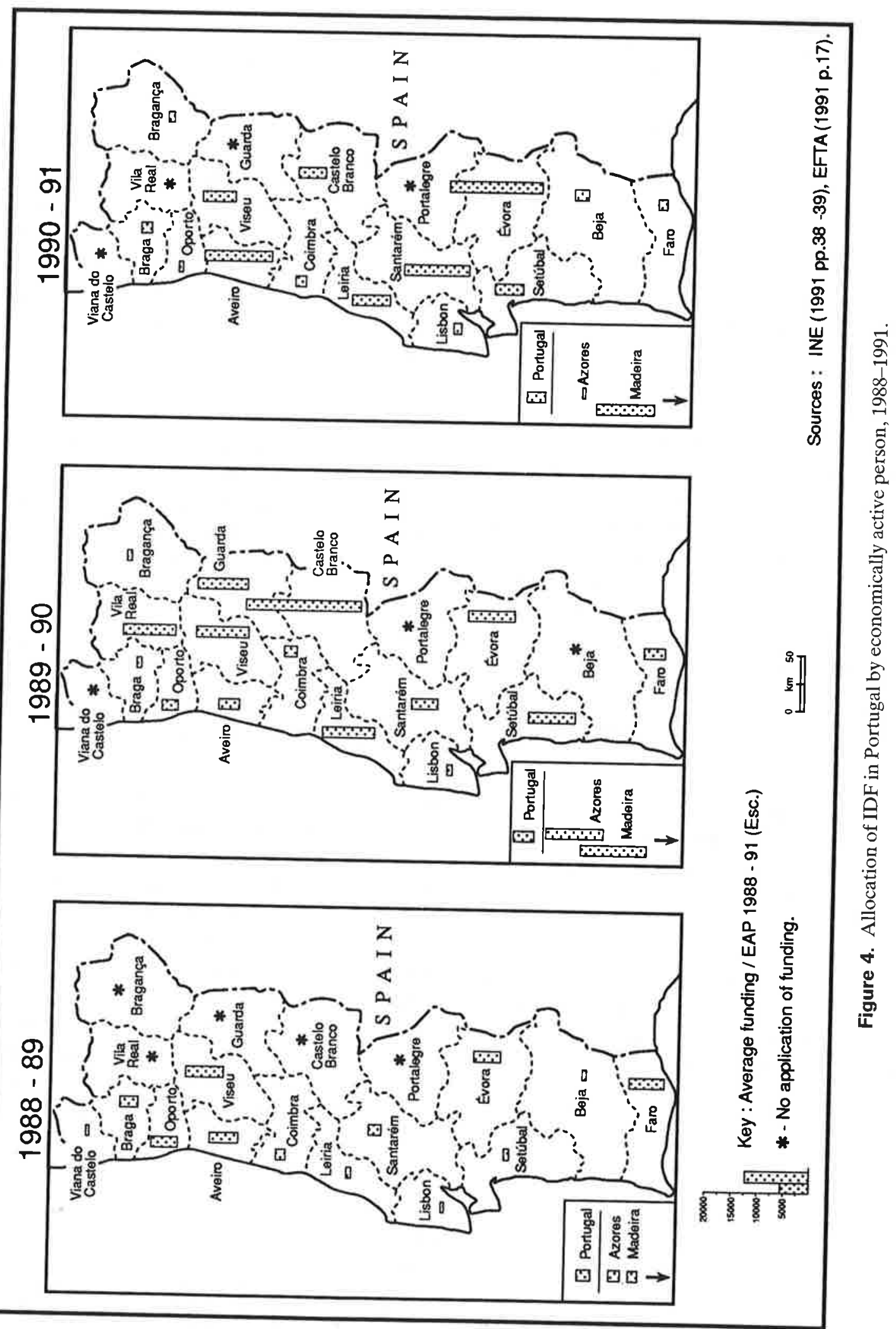


reactive (to applications from companies) rather than pro-active in promoting a decentralisation of IDF funds to other parts of the country and away from Lisbon. EFTA's policy (if there is one) appears to be erratic and is clearly not conducive (in spatial terms) to the overall efficacy of this particular instrument.

\section{Conclusion}

It is clear from this discussion that the thirteenth year of IDF activity showed a record rise in lending activities (the fourteenth year saw a levelling out at this newly established level) and represented an important source of (regional) development potential within Portugal. This improved performance was facilitated by more favourable conditions in the Portuguese economy in general. Strong investment from both foreign and domestic sources, coupled with improved financial situations in those firms receiving assistance, meant that IDF loan repayments were prompt and, in some cases, ahead of schedule. This more fluid situation helped both the administration of the Fund and the output of the firms involved. The process of Portugal's industrial modernisation and the efficiency with which it can be achieved is therefore slowly, but most definitely, improving through the mechanism of the IDF.

However, and although the scale of the figures involved represent a substantial input to the microscale development of some Portuguese companies, there is still considerable doubt surrounding the spatial efficacy of IDF's activities. Given the wave of documented industrialisation and an increase in entrepreneurship in the rural and interior areas of Portugal, it seems strange (not to mention illogical) to continue to ignore those unique spatial demands. EFTA contest that their applications mirror the development make-up in Portugal and the overall distribution of both economic activities and population (RAIMUNDO, 1991, p. A11) throughout the country. Certainly, on the basis of the core-periphery dichotomy shown in Figure 3 the interior only accounts for around one-fifth of all manufacturing enterprises in Portugal and one-tenth of overall manufacturing employment (INE, 1989). In relative terms these are small proportions but, for the absolute numbers of individuals concerned (over 57,000 personnel), it is still their livelihood at stake. Conse- quently, it must be asked if this IDF disclaimer is now a good enough justification, especially as the demands from the Portuguese 'regions' have grown and will continue to become more vociferous the longer their specific requirements are passed over.

In fairness, the IDF has come a long way since its establishment in 1977 and Figure 4 illustrates part of this progress. However, EFTA's policy towards the 'regions' can be considered erratic, disjointed and inconsistent, with some peripheral border counties benefiting one year and then, the next, seeing the orientation of funds drift back towards the coastal distritos.

On balance, there are still major improvements to be made to the IDF and plenty of time (another 9 years) in which to complete those changes. The Fund has gathered both momentum and credibility; it now needs someone or somebody with strength of mind and clarity of purpose to hear the 'regional voice' and to tailor the loans accordingly.

To that end, this paper recommends EFTA to instruct its steering committee (in the BFE) to canvass for more loan applications amongst the newlyindustrialising and the currently restructuring factories in the central eastern interior of Portugal. Once identified, the BFE should then treat such requests for assistance with sympathy. The IDF should reassert its influence (since it has undoubtedly suffered from the EC's publicity onslaught) as an aid agency with the potential to change Portugal's regional structures. It should actively advertise, promote and campaign for greater recognition and that awareness should be engendered not just within Portugal but throughout the whole of the nascent European Economic Area. Only then will the Fund improve its chances of truly and effectively "supporting projects located in (Portugal's) less industrialised regions" (EFTA, 1991 p. 3).

\section{Notes}

1. IAPMEI is the Portuguese small firms agency.

2. PEDIP is the jointly funded government-EC programme for the development of Portuguese industry.

3. The obvious problem with this result is that we have no data relating to employment within each of the firms 
helped by IDF and in each of the county districts. We cannot, therefore, create a more accurate illustration linking funding with jobs (both newly created and/or those safeguarded by the EFTA fund).

4. Exchange rates have been calculated on the basis of approximately 250 escudos $=£ 1$ sterling (January 1991).

\section{References}

ARANTES, P. (1991) O segredo do cofre Europeu, Port. Exame-Edição Especial, 27-A, 84-88.

BANCO DE FOMENTO E EXTERIOR (1990) Relatório e Contas 1989. BFE, Lisboa.

BLUM, P. (1992) Better times on the way in Madeira, Financial Times Survey, 17 June.

BOGDANOWICZ-BINDERT, C. A. (1983) Portugal, Turkey and Peru: three successful stabilisation programmes under the auspices of the IMF, Wld Dev., 11, 65-70.

CAETANO, L. DE J. (1986) A Indústria no Distrito de Aveiro, two volumes. CCRC, Coimbra.

CANHA, I. (1991) Recursos humanos: um filão por explorar, Port. Exame-Edição Especial, 27-A, 4447.

CORKHILL, D. (1991) Menos estado, melhor estado: Portugal's privatisation programme, J. ACIS, 4(1), 4148.

EATON, M. D. (1988) The textile and clothing industry of Portugal's central region: an examination of the impact of international production processes in the European Periphery, Unpublished doctoral thesis, University of Exeter.

EATON, M. D. (1991) Industrial assistance in Portugalthe role of the EFTA Fund, Tijdschr. econ. soc. Geogr., 82, 163-176.

ECONOMIST INTELLIGENCE UNIT (1989) Madeira and the Azores, International Tourism Reports 2.

EUROPEAN FREE TRADE ASSOCIATION (1978) Fundo da EFTA para a Desenvolvimento Industrial de Portugal: Primeiro Relatório Anual. EFTA, Geneve.

EFTA (1987) EFTA-the European Free Trade Association. EFTA, Geneva.

EFTA (1990) The EFTA Industrial Development Fund for Portugal, Thirteenth Annual Report, February 1989January 1990. EFTA, Geneva.

EFTA (1991) The EFTA Industrial Development Fund for Portugal, Fourteenth Annual Report, February 1990January 1991. EFTA, Geneva.

European Industrial Relations Review (1989) New constitution in force, EIRR, 189, 9.

EUROPEAN INVESTMENT BANK (1989) Annual Report-1989. EIB, Luxembourg.

Expresso (1991) Vantagens comparatives da indústria Portuguesa, Expresso Suplemento, 29 June, 11-S.

FERRÃO, J. (1986) Indústria e valorização do capital, Unpublished doctoral thesis, Universidade de Lisboa.

FERRĀO, J. (1988) L'industrie au Portugal. Structures prodictives et Sociales dans des contextes diversifies Régionaux, Annls Géogr., 541, 308-329.

GASPAR, J. and JENSEN-BUTLER, C. (1992) Social, economic and cultural transformations in the Portuguese urban system, Int. J. urban reg. Res., 16, 442-461.

HUDSON, M. (1989) Portugal to 1993: investing in a European future, The Economist Intelligence Unit Special Report, 1157. EIU, London.

INSTITUTO NACIONAL DE ESTATÍSTICA (1989) Estatísticas Industriais 1986, Vol. II-Indústrias Transformadoras. INE, Lisboa.

INE (1991) Caracterização das Empresas Portuguesas. INE, Lisboa.

JOLIFFE, J. (1992) Open frontier scares a wild bunch, The European, 121, 12.

KENT, V. (1989) What about the workers? How average earnings, working hours and unemployment compare across the European Community, The Sunday Correspondent, 10 December, 12.

KOHLER, B. (1982) Political Forces in Spain, Greece and Portugal. Butterworth, London.

LEWIS, J. R., WILLIAMS, A. M., MARGARIDO, A. P. and OLIVEIRA, A. (1986) The development of smallscale manufacturing enterprises in central Portugal, in $O$ Financiamento do Desenvolvimento Regional e Local, pp. 85-127, Comissão de Coordenação da Regiāo Centro. CCRC, Coimbra.

LEWIS, J. R. and WILLIAMS, A. M. (1988) Factories in fields: small manufacturing firms in rural southern Europe, in Peripheralisation and Industrial Change, pp. 113-130. G. J. R. Linge (Ed.). Croom Helm, London.

MACHADO, D. P. (1987) A critique of Thomas C. Bruneau's Politics and Nationhood-Post Revolutionary Portugal, Iberian Stud., 16, 115-134.

MINISTÉRIO DOS NEGÓCIOS ESTRANGEIROS (1987) Portugal nas Comunidades Europeias, Primeiro Ano-1986. MNE, Lisboa

MNE (1988) Portugal nas Comunidades Europeias, Segundo Ano-1987. MNE, Lisboa.

ORGANISATION FOR ECONOMIC COOPERATION AND DEVELOPMENT (1989) Economic Survey Portugal-1988/89. OECD, Paris.

OECD (1991) OECD Economic Outlook, 49, 99-100. OECD, Paris.

RAIMUNDO, O. (1991) Resultados do censo-91: Portugal está a envelhecer, Expresso Sábado, 22 June, A11.

RODRIGUES, J. N. (1991) O barato paga-se caro, Port. Exame-Ediçâo Especial, 27-A, 96-100.

SILVA, C. P. DA (1992) O litoral Português: conflito de interesses, Paper to ACIS Conference, UIMP, Santander.

SYRETT, S. (1991) Capital, state and local action: the emergence of local economic initiatives in central Portugal, Unpublished doctoral thesis, University of Exeter.

Wall Street Journal (1984) World Bank approves \$225 million in loans, Wall Street Journal, 30 May.

WILLIAMS, A. M. (1992) The Portuguese economy in transition, J. ACIS , 5(2), 30-39.

WISE, P. (1990) Foreign cash powers a boom in Portugal, The European, 4, 20. 